\title{
O nieoczywistości metafor
}

\author{
Magdalena ZawisŁawsKa, Metafora w języku nauki. \\ Na przykładzie nauk przyrodniczych, Wydział Polonistyki \\ Uniwersytetu Warszawskiego, Warszawa 2011, s. 253.
}

Autorka pracy jest językoznawcą, o ile możemy się domyślać, należącą do stronnictwa kognitywnego. Recenzowana książka składa się ze wstępu, sześciu rozdziałów głównych i podsumowania. Stanowi próbę uporania się z zagadnieniem metafor, które faktycznie łatwiej zegzemplifikować, niźli wyeksplikować, nawet $\mathrm{w}$ ograniczonym zakresie. Głównym powodem jest istnienie kilku schematów wyjaśnień, w tym klasycznego Arystotelesowskiego, interakcyjnego, pragmatycznego, predykacyjnego, kognitywnego oraz integracyjno-kognitywnego.

Metaforyzacja w sensie klasycznym polega na przeniesieniu znaczenia, przy czym nie istnieją ostre granice między zakresami metafory a katachrezy (rozszerzenia pola semantycznego jakiegoś wyrażenia, także przez skojarzenie nielogiczne), metonimii (metafory wyrażającej faktyczną zależność), synekdochy (metonimii wskazującej na jakieś zjawisko przy pomocy nazwy innego) i analogii. Współcześnie nierzadko metonimie łączy się z synekdochami w jedną kategorię.

Stagiryta klasyfikuje metafory w aspekcie kierunku przenoszenia znaczeń w hierarchii abstraktów: $\mathrm{z}$ rodzaju na gatunek, z gatunku na rodzaj, z gatunku na gatunek, $\mathrm{z}$ dodaniem analogii typu proporcjonalnego. Nie jest to jedyne rozwiązanie mieszczące się w paradygmacie klasycznym. Za wyróżnione przypadki 
przeniesienia uznać można - jak Kwintylian ${ }^{1}$ - translacje znaczeń z kategorii żywin na byty nieożywione oraz odwrotnie, a także w obrębie kategorii obiektów ożywionych, względnie nieożywionych. Tak czy inaczej metafory w rozumieniu klasycznym są z punktu widzenia przyrodoznawstwa bezpłodne, skoro nie generują nadwyżek semantycznych, będąc tylko ozdobnikami.

Współcześnie odrzuca się tę interpretację, podobnie jak pogląd, jakoby metaforę dało się uznać za eliptyczny wyraz podobieństwa. Poza paradygmatem klasycznym znajduje się pogląd Ivora Armstronga Richardsa, ${ }^{2}$ określony przez Maxa Blacka mianem interakcyjnego: dwie myśli oddziałują, tworząc społem ogólniejsze znaczenie. ${ }^{3}$ Metafora ma zawsze dwa obiekty: główny (principal) oraz pomocniczy (subsidiary), na przykład w wypowiedzi „,człowiek jest wilkiem" człowiek jest obiektem głównym, a wilk pomocniczym. Sam Richards w niejasny sposób pisał o temacie (tenor) oraz nośniku (vehicle) ${ }^{4}$ Przyjęło się uważać pierwszy za obiekt główny, a drugi za pomocniczy.

Jedne metafory po prostu okazują się udane, zaś inne - nie, dla czego nie istnieje jakiś ogólny powód. ${ }^{5} \mathrm{~W}$ drugim artykule Black wzmacnia swoje twierdzenie o twórczej roli pewnych metafor, ${ }^{6}$ które określa mianem mocnych (strong $)^{7}$ — bo przechodzą ocenę pod kątem ,stosowności, wierności, stronniczości, czy powierzchowności”. Ich przeciwieństwem są metafory słabe (weak), przypominające nieśmieszne dowcipy. Interakcja jest teraz rozumiana jako oddziaływanie dwóch układów wynikające z analogii strukturalnych „częściowo

\footnotetext{
${ }^{1}$ Kwintylian, Institutio Oratoria, 8, 6.9-13; „Metaphora brevior est similitudo”, w: KwinTYLIAN, Institutio..., 8, 6.4 .

${ }^{2}$ Ivor Armstrong Richards, The Philosophy of Rhetoric, Oxford University Press, Oxford 1936.

${ }^{3}$ Max Black, „Metaphor”, Proceedings of the Aristotelian Society - New Series 1954-1955, vol. 55 , s. 291-294.

${ }^{4}$ BLACK, „Metaphor...”, s. 294.

${ }^{5}$ BLACK, „Metaphor...”, s. 292.

${ }^{6}$ Max Black, „More about Metaphor”, Dialectica 1997, vol. 31, no. 3-4, s. 431-457; przedruk: Andrew Ortony (ed.), Metaphor and Thought, 2nd ed., Cambridge University Press, Cambridge 1993, s. 19-41.

${ }^{7}$ BLACK, „More about Metaphor...”, s. 440, 456.
} 
tworzonych, a częściowo odkrywanych”. Black pisze przy tej okazji o ,izomorfizmach", choć o tak daleko posuniętym podobieństwie nie może być przypadku mowy. W związku z tym metafora jest bliska modelowi: „każda metafora jest wierzchołkiem zanurzonego modelu". ${ }^{8}$ Mocnym wypowiedziom metaforycznym brak wartości logicznej: mogą za to być poprawne lub nie i dają nam wgląd w to, jakimi rzeczy faktycznie są. ${ }^{9}$

Według Searle'a metafory należy badać w aspekcie pragmatycznym, a nie semantycznym, próbując ustalić, co skłania odbiorców do rozumienia wypowiedzi konkretnego nadawcy (speaker's utterance meaning), iż ,S to $P$ ”, w znaczeniu , $S$ to $R " .{ }^{10}$ Zgodnie z koncepcją predykacyjną metafory polegają na przypisywaniu obiektom cech, których te nie posiadają. Jesteśmy wyposażeni w zdolność adekwatnej, niedosłownej interpretacji takich wypowiedzi. ${ }^{11}$ Według teorii kategoryzacyjnej metaforyzacja polega na tworzeniu doraźnej kategorii nadrzędnej obejmującej temat i nośnik wypowiedzi. ${ }^{12}$

Kognitywiści przypisują metaforom: wszechobecność (ubiquity); obecność dwóch rodzajów domen (źródłowej: source, oraz docelowej: target); tworzenie wyidealizowanych modeli poznawczych (idealized cognitive models); diachroniczność; jednokierunkowość (unidirectionality); niezmienniczość (invariance); niezbędność (necessity); twórczość (creativity); selektywość (focusing). ${ }^{13}$ $\mathrm{W}$ metaforze , $X$ to $Y$ ' za domenę źródłową $Y$, będącą eksplanansem, uznaje się tę prostszą i lepiej dostępną poznaniu zmysłowemu, a za docelową $X$, występu-

\footnotetext{
${ }^{8}$ BLACK, „More about Metaphor...”, s. 445.

${ }^{9}$ BLACK, „More about Metaphor...”, s. 456.

${ }^{10}$ John R. Searle, Expression and Meaning: Studies in the Theory of Speech Acts, Cambridge University Press, Cambridge 1979, s. 84; John R. Searle, „Metaphor”, w: Ortony (ed.), Metaphor and Thought..., s. 88.

${ }^{11}$ Sonia Sedivy, „Metaphoric Pictures, Pulsars, Platypuses”, Metaphor and Symbol 1997, vol. 12 , no. 2 , s. 101.

${ }^{12}$ Sam Glucksberg and Boaz Keysar, „How Metaphors Work”, w: Ortony (ed.), Metaphor and Thought..., s. 416-418; Sam Glucksberg and Boaz Keysar, „Understanding Metaphorical Comparisons: Beyond Similarity", Psychological Review 1990, vol. 97, no. 1, s. 12-13.

${ }^{13}$ Olaf JäKEL, „Hypotheses Revisited: The Cognitive Theory of Metaphor Applied to Religious Texts", metaphorik.de 02/2002, s. 21-22, http://www.metaphorik.de/02/jaekel.pdf (11.04.
} 2013). 
jącą w roli eksplanandum, tę bardziej abstrakcyjną. Tak czy inaczej postulat jednokierunkowości w referowanej formie nie jest bynajmniej niesporny. Niezmienniczość oznacza fakt, że niektóre relacje domeny źródłowej pozostają nienaruszone, odciskając się niejako na strukturze domeny docelowej. Za elementarny przykład odwzorowania (mappping) służy często przekształcenie domeny wysokości na domenę ilości, ${ }^{14}$ wedle reguły „wyżej to więcej, a niżej to mniej”. Lakoff sądzi, że lepsza zrozumiałość tej pierwszej wynika z faktu, iż żyjemy pod wpływem grawitacji. ${ }^{15}$

Fauconnier i Turner przemianowali kognitywny schemat odwzorowania na amalgamację czy też stapianie (blending), ${ }^{16}$ przy okazji go komplikując przez wprowadzenie dodatkowej przestrzeni uogólnionej czy też generycznej (generic), złożonej z elementów wspólnych dla dwóch przestrzeni wyjściowych. Służy ona jako pomoc w dopasowaniu (matching) tych elementów przestrzeni wyjściowej, które nadają się do amalgamacji. W amalgamacie pojawiają się zresztą nowe elementy pojawiające się drogą: złożeń zachodzących dzięki współobecności obiektów pochodzących z przestrzeni wyjściowych, uzupełniania elementami wiedzy o świecie, tudzież rozwoju amalgamatu zgodnie z własną logiką tego ostatniego. Koncepcja stapiania pozwala uniknąć kwestii kierunku odwzorowania domen.

Z powyższego przeglądu wynika, że metafora jest zjawiskiem zgoła nieoczywistym, nawet jeżeli niektóre próby jego wyjaśnienia skutkują raczej zaciemnieniem. Autorka (s. 82-83) opowiada się ostatecznie za teorią Fauconniera i Turnera.

Rozważając w rozdziale 4. przyczyny antypatii przyrodoznawców względem metafor, Zawisławska odwołuje się najpierw do tradycji Arystotelesow-

\footnotetext{
${ }^{14}$ George Lakoff, Women, Fire, and Dangerous Things: What Categories Reveal about the Mind, University of Chicago Press, Chicago 1987, s. 276.

${ }^{15}$ W sformułowaniu „wyżej to dobrze, zaś niżej to źle” zyskuje to aspekt aksjologiczny, który Tomasz Krzeszowski wywodzi z idei Wielkiego Łańcucha Bytu: Tomasz Krzeszowski, Angels and Devils in Hell: Elements of Axiology in Semantics, Energeia, Warszawa 1997; Tomasz KRZESZOwSKI, Aksjologiczne aspekty semantyki językowej, Wydawnictwo UMK, Toruń 1999.

${ }^{16}$ Gilles Fauconnier and Mark Turner, „Rethinking Metaphor”, w: Raymond W. GibBs (ed.), The Cambridge Handbook of Metaphor and Thought, Cambridge University Press, Cambridge 2008, s. 53-66.
} 
skiej, a potem do nowożytnego ideału wiedzy pewnej, dostarczanej przez naukę zbudowaną na wzór geometrii. W zmatematyzowanej formie wyraził to Leibniz hasłem „Calculemus!” Oczyszczenie języka nauki było tym bardziej konieczne, że obok niej funkcjonował przeciwwzorzec jasności w postaci piśmiennictwa alchemicznego. Rehabilitacja metafor dokonała się w dwudziestym wieku wraz z zarzuceniem logicystyczno-redukcjonistycznych modeli nauki oraz powstaniem nieklasycznych koncepcji metafory.

W ich kontekście zidentyfikowano przyczyny zniekształceń i błędów, do których może doprowadzić metaforyzacja. Najważniejszą okazuje się selektywność tego procesu, który jedne składowe domen docelowych uwydatnia, a inne ukrywa. Rzecz jasna, robi swoje niewiedza odbiorców, nawet zawodowych naukowców, którzy chcąc się dowiedzieć czegoś spoza swojej specjalizacji są skazani na popularne prezentacje wyrażane właśnie w języku metaforycznym, często przez dziennikarzy-nieuków. Jaskrawymi przykładami są: „,mózg to komputer”, „DNA to dusza”, „,ewolucja to dobór naturalny”, „Wszechświat to balon”; jeszcze gorzej jest w humanistyce i naukach społecznych: ,psychika to góra lodowa” (w sensie: nieświadomość to zanurzona, niewidoczna część psychiki), „gospodarka to wojna”. Rozpowszechniona niechęć do czytania dłuższych tekstów jeszcze pogarsza sprawę.

Metafory wykazują swojego rodzaju uporczywość. Autorka podaje przykład sformułowanej przez Daniela Dennetta koncepcji umysłu, mającej zastąpić metaforę kartezjańską i wyrażonej przy pomocy innego zestawu metafor. W ogólności Zawisławska wylicza następujące funkcje metafor: (1) heurystyczną, (2) ontologiczno-postulatywną, (3) modelującą, (4) referencyjną, (5) dydaktyczno-objaśniającą, (6) katachretyczno-nazywającą, (7) pragmatyczną, (8) estetyczną. W (2) chodzi o postulowanie istnienia nowych obiektów w rodzaju czarnych dziur w takich dziedzinach jak astrofizyka. W (8) chodzi o niedosłowny styl pisania prac naukowych, w którym użycie metafor stanowi nową normę stylistyczną. Autorka za najważniejsze z nich uznała funkcję poznawczą, stanowiącą połączenie funkcji (1) i (2); a także dydaktyczno-objaśniającą oraz katachretyczną. Z kolei funkcja poznawcza - zgodnie $\mathrm{z}$ cytowanym powyżej poglądem Blacka - wiąże się z tworzeniem modeli rzeczywistości. 
Wiąże się z tym niebezpieczeństwo dosłownego traktowania obiektów opisywanych przez metafory, a tymczasem nierzadko realne jest tylko to, z czym ów opisywany byt porównujemy. Dobrym przykładem jest metafora „atom to układ planetarny": znany i wyobrażalny jest tylko ten drugi, o pierwszym nie wiemy zgoła nic (s. 132). Takie stwierdzenie w dosłownym rozumieniu jest wprawdzie za mocne, jednak z pewnością pewne postulowane własności atomu nie są uogólnieniem doświadczenia, stanowiąc za to efekty procesu metaforyzacji.

W rozdziale przedostatnim autorka dokonuje przeglądu historycznych zmian w metaforyzacji budowy i funkcji mózgu: od siedziby duszy do analogonu komputera. Zestawia przy okazji różnice między mózgiem a komputerem (s. 213); należy zaznaczyć że zestawienie to zawiera błąd: komputer dzięki zaprogramowaniu $\mathrm{z}$ definicji posiada syntaktykę. $\mathrm{Z}$ rozważań w tej części książki wynika, że niezależnie od adekwatności metafory komputerowej skutecznie wytwarza ona iluzję zrozumienia sposobu funkcjonowania psychiki ludzkiej. W ostatnim, 6. rozdziale znajdujemy opis wpływu metafor na pozanaukowy obraz świata, czyli tego, jak język nauki rykoszetem odbija się na myśleniu potocznym. Za przykład służą metafory opisujące funkcjonowanie DNA. Autorka wskazuje na niebezpieczeństwa związane $\mathrm{z}$ determinizmem implikowanym przez tego rodzaju obrazowanie.

W książce przydałby się chociaż indeks nazwisk, a nie zaszkodziłaby także lista przytoczonych metafor. Razi niechlujny skład formuł logicznych, w których symbole nie wiedzieć czemu złożono kursywą. 